\title{
30. COMPARISON BETWEEN LABORATORY-DETERMINED PHYSICAL PROPERTIES AND DOWNHOLE MEASUREMENTS IN OUTER BENGAL FAN DEPOSITS ${ }^{1}$
}

\author{
Andreas Wetzel, ${ }^{2,3}$, Colin Williams, ${ }^{4,5}$, Heidemarie Kassens, ${ }^{6}$ Greg Leger, ${ }^{7}$ and Christian Auroux ${ }^{8,9}$
}

\begin{abstract}
Mass physical property data determined aboard ship and by downhole logging correlate to a varying degree with each other depending on lithology and the parameter determined.

Compressional-wave velocity values determined on board are of low reliability because they are heavily affected by drilling disturbance. The disturbance is probably related to the opening of microcracks during drilling. For porosity (and inversely related wet-bulk density) the pattern of divergence between laboratory and downhole measurements seems to be related to lithology. Major differences between on-board and in-situ determinations occur in mud-dominated intervals and are probably due to inaccurate logging measurements. These probably result from tool stand-off in the soft sediments rather than mineralogical effects.

The sonic log-derived porosities appear to be accurate, independent of lithology, although this conclusion must remain tentative because of poor core recovery within the silt-rich turbidite intervals. An independent check of the accuracy of the various techniques for measuring porosity and wet-bulk density is provided by the compression test results. These results are in good agreement with all logging data in silt-dominated intervals and in good agreement with sonic log data and laboratory data only in the mud-dominated sections. These results indicate that, until the techniques for eccentering the neutron and density tools are improved, only the sonic and resistivity logs should be used for porosity determinations in these high-porosity sediments. Because the applicability of the resistivity and sonic-velocity transforms for logging signals remain uncertain, core measurements are necessary for calibrations.
\end{abstract}

\section{INTRODUCTION}

Determination of mass physical properties such as porosity, wet-bulk density, and compressional-wave velocity is a routine procedure during JOIDES Resolution cruises. To obtain these data, two different measuring principles are applied. (1) Laboratory determinations on core samples (e.g., Boyce, 1976) and (2) downhole measurements by wireline logging (e.g., Borehole Research Group, 1987; Cochran, Stow, et al., 1989). Both methods for evaluation of mass physical property data are subject to errors. Laboratory measurements on retrieved cores are affected by drilling disturbance and rebound (e.g., Demars and Nacci, 1978, Nichols, 1980, Karig and Salisbury, 1986). Rebound results from the release of overburden stress, which allows expansion of the drilled sediments. Core expansion leads to an increase in porosity and a decrease in wet-bulk density. Consequently, the porosity values obtained onboard are normally higher and wet-bulk density values are lower than in-situ. However, the effect of rebound on porosity and wet-bulk density should be subordinate because for these parameters the water volume

\footnotetext{
${ }^{1}$ Cochran, J. R., Stow, D.A.V., et al., 1990. Proc. ODP, Sci. Results, 116: College Station, TX (Ocean Drilling Program).

${ }^{2}$ Geologisches Institut, Sigwartstrasse 10, D 7400 Tübingen, Federal Republic of Germany.

${ }^{3}$ Present address: Geologisches Institut, Bernoullistrasse 32, $\mathrm{CH} 4056$ Basel, Switzerland.

${ }^{4}$ Lamont-Doherty Geological Observatory, Palisades, New York 10964, U.S.A.

5 Present address: U.S. Geological Survey, 345 Middlefield Road, Mail Stop 923, Menlo Park, CA 94025, U.S.A.

${ }^{6}$ Geologisches Institut, Olshausenstrasse 40-60, D 2300 Kiel, Federal Republic of Germany.

${ }^{7}$ Department of Oceanography, Dalhousie University, Halifax, Nova Scotia B3H 4J1, Canada.

${ }^{8}$ Ocean Drilling Program, Texas A\&M University, 1000 Discovery Drive, College Station, TX 77840, U.S.A.

9 Present address: 11 Avenue Michel Chevalier, F 06130 Grasse, France.
}

within the sample was determined and the access of free water during coring and sampling was restricted.

Even if effects of core disturbance due to drilling can be minimized by the use of samples that show undisturbed sedimentary structures of known geometry (e.g., biogenic traces), rebound can hardly be estimated. However, the effects of rebound can be evaluated by compression tests in shore-based laboratory studies (Demars and Nacci, 1978, Marine Geotechnical Consortium, 1986); the sample is compressed by known different stresses and its response is recorded. If the overburden effective stress is applied, porosity values lower than in-situ are obtained as stated by Schmertmann (1955). However, from the consolidation characteristics, the porosity effective stress path for "first-loading"' can be reconstructed (e.g., Terzaghi and Peck, 1967), and then reasonable porosity values for in-situ effective stress can be obtained.

In contrast, wireline logging data from in-situ measurements are less affected by rebound or drilling disturbance. However, there are at least two possible sources of errors. First, logging measurements that require contact between the tool and the borehole wall are adversely affected by hole roughness and tool stand-off. Second, many physical properties are not measured directly with logging tools but are instead determined from empirical relationships between measured quantities (e.g., Compton scattering of gamma rays, neutron slow-down lengths, resistivity, acoustic velocity) and physical properties such as wet-bulk density, porosity, and permeability (Serra, 1984; Ellis, 1987). These relationships often do not apply to all lithologies or environments. For example, well logs have been calibrated in a number of oil-bearing sedimentary sequences, but the high-porosity sediments drilled and logged on many Ocean Drilling Program (ODP) legs lie outside the range of most petroleum industry calibrations.

This paper compares Leg 116 downhole measurement data with shipboard laboratory determinations as well as porosity values corrected for release of overburden by compression 
tests. In this way three different measurements can be compared and the source and range of error estimated.

\section{AREA OF INVESTIGATION}

The outer Bengal Fan deposits investigated in this study were drilled during ODP Leg 116 at three sites about $800 \mathrm{~km}$ south of Sri Lanka in 4,700 to $4,750 \mathrm{~m}$ water depth (Fig. 1). The sites are located about 8-10 km away from each other on different fault blocks. The sediments were mainly deposited from turbidity currents originating from the Ganges Brahmaputra Delta (gray sandy, silty turbidites), the adjacent shelf (green silty to muddy turbidites), and Nikitin Seamounts (green pelagic turbidites) (Stow et al., this volume). Pelagic intervals also occur at the top of turbidites. The main lithologic units are given in Figure 2.

At all three sites sediments of similar composition and lithology were found; they differ only in the thickness of the defined lithologic units (Fig. 2). Sedimentation is dominated by turbidites for which an average frequency of $>500 \mathrm{yr} /$ event was calculated (Stow et al., this volume). The sedimentation rate is on average $20-30 \mathrm{~cm} / \mathrm{k} . \mathrm{y}$. (Site Chapters, Cochran, Stow, et al., 1989).

In this paper only investigations at Sites 718 and 719 are discussed; the lithologies at these sites are described in more detail below.
At Site 718 the following lithologic units were defined:

I $\quad 0.0-2.0 \mathrm{~m}$ : clay and calcareous clay

II $\quad 2.0-100.0 \mathrm{~m}$ : micaceous silt and silty mud turbidites

III + IV 100.0-185.0 m: mud turbidites with thin interbedded pelagic clays and scattered silty mud turbidites

VA $185.0-605.0 \mathrm{~m}$ : silt and silty mud turbidites with thin, sporadic interbeds of pelagic clays

VB 605.0-961.0 m: silt and silty mud turbidites with up to 20 -m-thick intervals of interbedded mud turbidites, biogenic mud turbidites, and pelagic clays.

The section drilled at Site 719 was divided into the following lithologic units:

I $\quad 0.0-4.0 \mathrm{~m}$ : clay and calcareous clay and mud

II $4.0-135.0 \mathrm{~m}$ : micaceous silt and silty turbidites with thin intervening muds

III 135.0-207.0 m: mud turbidites and biogenic mud turbidites with thin interbedded pelagic clays

IVA $207.0-240.0 \mathrm{~m}$ : silt turbidites with thin muds and mud turbidites

IVB 240.0-357.0 m: mud turbidites with thin interbedded pelagic clays

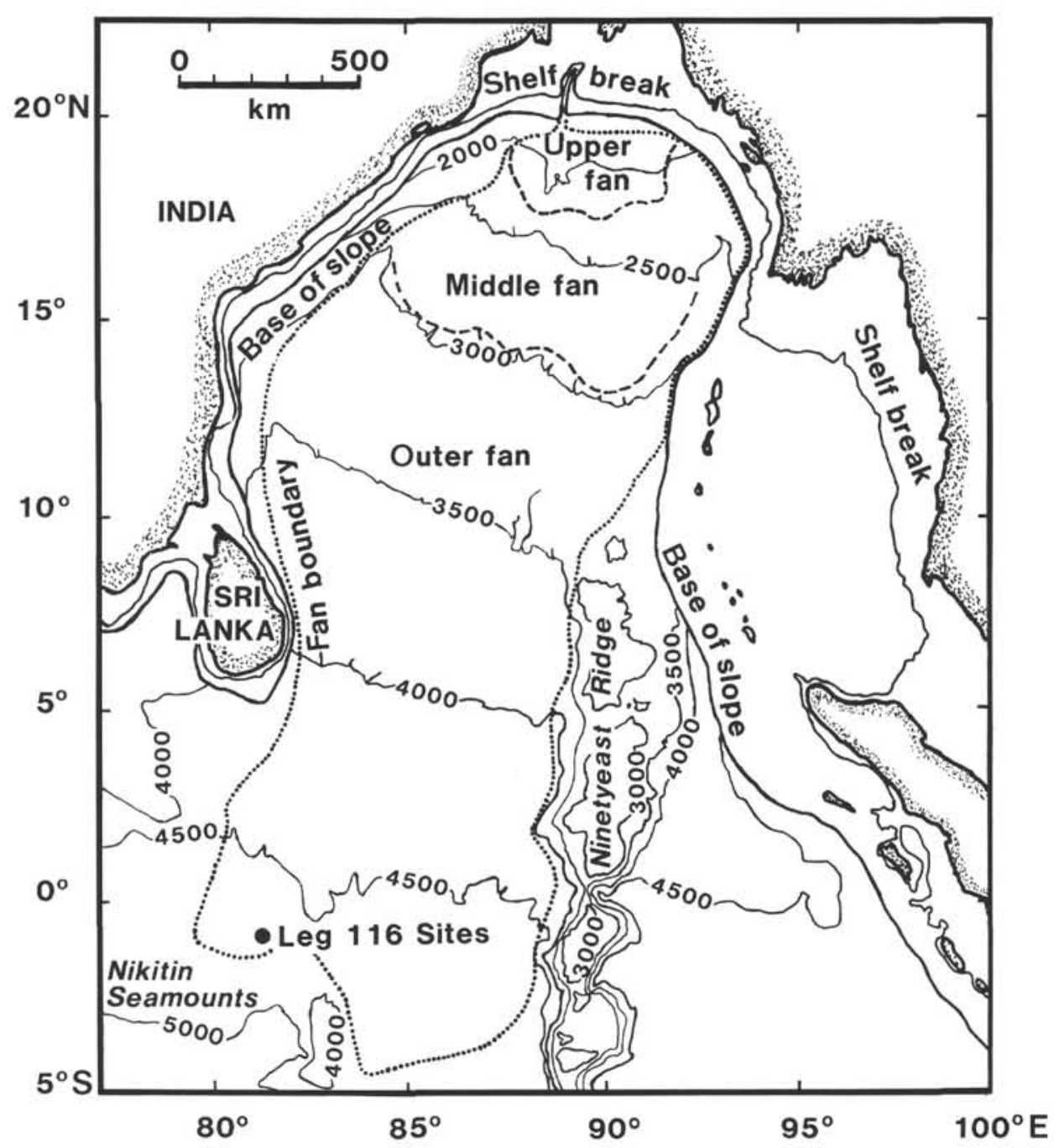

Figure 1. Location of sites drilled during Leg 116. Depth contour lines are in meters. 


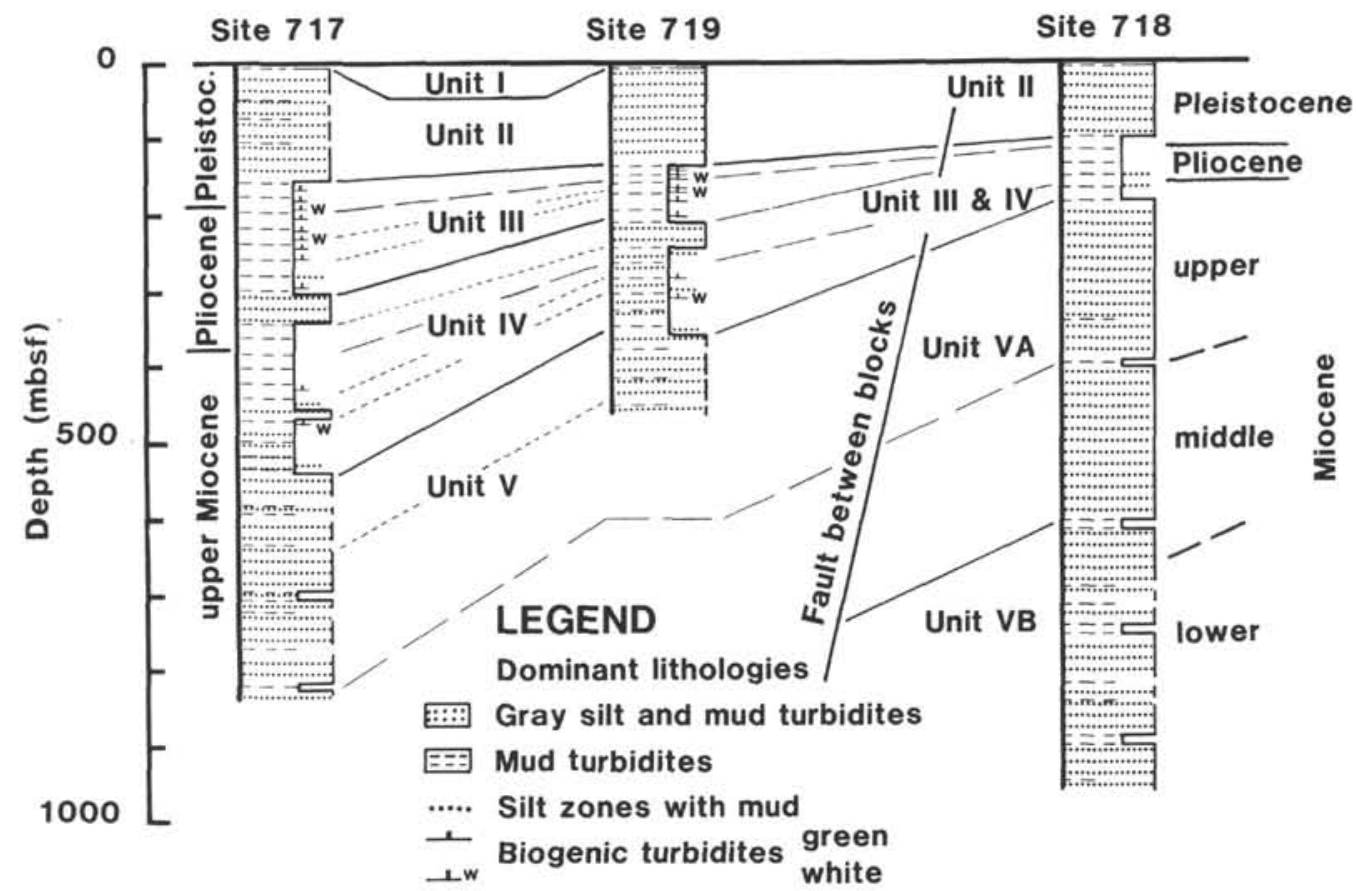

Figure 2. Dominant lithologic units as defined at the drilled sites for outer Bengal Fan deposits.

V 357.0-460.2 m: silt and silty mud turbidites with rare intervals of pelagic clay and organic-rich mud turbidites.

\section{METHODS}

The laboratory procedures and logging instrumentation are described in detail in Explanatory Notes (Cochran, Stow, et al., 1989). Mass physical properties were determined immediately after a core was split to prevent desiccation of samples and its influence on mass physical properties. Compressionalwave velocity was determined by using a Hamilton frame. The accuracy of measurement is $\pm 2.5 \%$ (e.g., Boyce, 1976). Wet-bulk density and porosity were calculated from gravimetric and volumetric measurements. Wet-bulk density is the weight of the wet sample divided by its volume. Porosity is the ratio of volume of water lost during drying, to the volume of water-saturated wet sample. Wet-bulk density $\left(d_{w}\right)$ and porosity $(n)$ are inversely related to each other when the sediment contains grains of known density $\rho_{s}$ and pore water of known density $\rho_{f}$. Then

$$
d w\left[\mathrm{~g} / \mathrm{cm}^{3}\right]=(n / 100) \rho_{\mathrm{f}}+(1-n / 100) \rho_{s}
$$

Taking all possible measuring inaccuracies into account, the relative error in mass physical property determinations due to laboratory procedures is in the range of $\pm 2.5 \%$ (e.g., Boyce, 1976).

Compression tests were carried out on some selected whole-round samples. They were uniaxially compressed under confined conditions in a so-called oedometer (for details see Terzaghi and Peck, 1967; Marine Geotechnical Consortium, 1986; Wetzel, this volume). These tests provide information on a sample's response to loading. During a test, different effective stresses are applied and the deformation of a sample is recorded. From these measurements, compressibility and porosity at any effective stress level can be determined.

A porosity value lower than in-situ is reached if the applied stress is equal to the overburden effective stress (e.g., Schmertmann, 1955). The porosity difference between in-situ porosity and that in compression tests at overburden effective stress is mainly due to reloading. A correction was applied that took into account the reloading effect. The correction is based on the reconstructed first loading path as well as the rebound characteristics of the samples within the actual range of overburden effective stress. It is in the range of $3 \%-8 \%$ porosity. Furthermore, the calculation of overburden effective stress is subject to a relatively low error of $\pm 5 \%$ within the studied sequences, because there was no indication for overpressuring.

In-situ porosity can be estimated from four of the well-log measurements recorded during Leg 116. These are the compensated neutron porosity, dual induction resistivity, bulk density, and compressional-wave velocity logs. The operating principles for these tools are summarized in the Explanatory Notes (Cochran, Stow et al., 1989), Ellis (1987), and Serra (1984). The compensated neutron tool is the only one of the four that comes close to a direct measurement of porosity. High-energy neutrons are released from an AmBe source, and the number of neutrons arriving at short-spacing and longspacing detectors are counted. The ratio of the two count rates is related to the neutron slow-down-length of the formation. Because the neutrons are slowed primarily by collisions with hydrogen ions, the hydrogen content of the formation can be determined. The conversion from hydrogen content to porosity is straightforward if (1) any effects from borehole fluid are accounted for and (2) the apparent porosity is corrected for the hydroxyl content of any clay minerals present (Serra, 1984).

The empirical Archie (1942) relationship between resistivity and porosity can be successfully applied to high-porosity terrigenous sediments (Jarrard et al., 1989). The Archie equation is given by

$$
R_{t} / R_{w}=a / \Phi^{\mathrm{m}}
$$

where $R_{t}$ is the formation resistivity, $R_{w}$ is the formation water resistivity, $\Phi$ is the fractional porosity, and $a$ and $m$ are lithology-dependent constants. The Archie equation can be 
applied to clay-rich sediments if the porosity is sufficiently high (>30\%; Jarrard et al., 1989), and high-conductivity secondary minerals are not present.

Just as with the laboratory physical properties measurements, porosity can be determined from the bulk density log if an accurate estimate of the formation grain density is available. The density log is derived from measurements of gamma-ray attenuation due to Compton scattering. This attenuation is directly related to the bulk density of the formation. Because the density tool is a pad device that must be held against the borehole wall, the log is susceptible to errors resulting from hole roughness and inadequate padding (Ellis, 1987).

The long-spacing sonic tool is less sensitive to hole shape (Ellis, 1987), but the correlation between compressional-wave velocity and porosity is much less certain. The Wyllie time average equation (Wyllie et al., 1956) provides an accurate estimate for porosities of less than $30 \%$ but greatly overestimates the porosity of high-porosity sediments. For the sonicderived porosities discussed in this paper, the Raymer et al. (1980) transform was used. The Raymer equations are

$$
\begin{aligned}
& V=(1-\Phi)^{2} V_{m}+\Phi V_{f} \quad(\Phi \leq 0.37) \\
& V=0.1 V_{1} V_{2} /\left(V_{1}(\Phi-0.37)-V_{2}(\Phi-0.47)\right) \\
& (0.37 \leq \Phi \geq 0.47) \\
& 1 / \rho V^{2}=\Phi \rho^{f} V_{f}^{2}+(1-\Phi) / \Phi_{m} V_{m}^{2} \quad(\Phi>0.47)
\end{aligned}
$$

where $\Phi$ is the porosity, $V$ is the formation sonic velocity, $V_{m}$ is the matrix velocity, $V_{f}$ is the fluid velocity, $V_{1}$ is the formation velocity for a $\Phi$ of $0.37, V_{2}$ is the velocity for a $\Phi$ of 0.47 , and $\rho, \rho_{m}$ and $\rho_{p}$ are the bulk, matrix, and fluid densities, respectively.

\section{RESULTS}

The mass physical properties data obtained at Sites 718 and 719 by wireline logging and laboratory determinations are shown in Figures 3, 4 (backpocket), and 5 (backpocket). The different properties are discussed separately for each site.

\section{Site 719}

Figure 3 shows the logs from Hole 719B, along with core recovery and indication of whether the sediment is silt- or clay-rich. Core recovery was especially poor in the silt turbidites of Units II and V, but the responses of the neutron porosity, bulk density, and compressional-wave velocity logs clearly reflect the lithologic variation. The natural gamma-ray curve is usually an excellent indicator of the presence or absence of clay (Serra, 1984), but in this case the curve is relatively featureless through sections of alternating clay and silts. This is probably due to the abundance of micas and radioactive secondary minerals within the silt turbidites (see Site Chapters in Cochran, Stow, et al., (1989).

The wireline log values are compared with core measurements in Figure 4 (backpocket). The "sonic caliper" is an approximation derived from sonic transit time measurements; the mechanical caliper was not working during Leg 116. The core-porosity values have not been corrected for rebound because porosity was determined by measuring the volume of water within the sample and there was no, or only a strongly restricted, access of free water to the sample (in contrast to the statement of Hamilton, 1976).

As Figure 3 shows, the resistivity log from Hole 719B is relatively featureless. It is not clear whether this reflects borehole disturbance or anomalous conductivity within the silt turbidites. Whatever the reason, the resistivity log proved completely inadequate for porosity characterization, despite the fact that resistivity-derived porosities have proven accurate in other ODP boreholes (Jarrard et al., 1989).

Compressional-wave velocity values determined in-situ by the sonic log are generally higher than the on-board measurements. The latter were evidently influenced by core disturbance; for instance, microcracks and rebound. Because of this disturbance, the core compressional-wave velocity is often close to that of seawater (approximately $1550 \mathrm{~m} / \mathrm{s}$ ) within the upper $250 \mathrm{~m}$. When sediments become increasingly indurated and stiff with depth, samples are less affected by drilling, and the compressional-wave velocities of an increasing number of samples come closer to the logging values. Porosity was estimated using the Raymer equation discussed above. As Figure 4 (backpocket) shows, the resulting sonic porosity is generally in agreement with the core measurements. Some disagreement is expected, as the $\log$ velocities are averaged over the 2 - to $4-\mathrm{m}$ spacing of the receivers, and the core measurements are not corrected for the effects of rebound. The compression test measurements confirm that the assumption on the effect of rebound is correct.

The situation is reversed for the bulk-density log and core measurements. The density log curve is highly variable, with only the peak values equaling the core sample densities. This underestimation results from inadequate padding of the density tool to the borehole wall, especially in the intervals of large hole size indicated by the sonic caliper. Consequently, the density porosity estimate is, on average, approximately $8 \%$ greater than the rebound-corrected core measurements. Only within the silt turbidites of Unit V does the density porosity approach the in-situ porosity.

Similarly, the neutron-porosity curve also overestimates the in-situ porosity, especially within Units III and IV. This deviation from the in-situ value is the result of tool stand-off and the presence of clay minerals. The predominant clays in the mud turbidites of Units III and IV are illites and smectites (Cochran, Stow, et al., 1989) that have an intrinsic hydrogen content determined by the presence of $(\mathrm{OH})_{4}$. A neutronporosity $\log$ of $100 \%$ illite or smectite would record an additional porosity of $10 \%$ due to hydroxyl content (Ellis, 1987). Typical clay contents within these units range from $40 \%$ to $90 \%$ (Cochran, Stow, et al., 1989), so the neutron-porosity log should overestimate the in-situ porosity by approximately $5 \%$, on average. Typically, the sensitivity of the natural gamma radiation curve to clay content provides a means of correcting the neutron-log response but, as mentioned above, the gamma-ray curve from Hole 719B is relatively insensitive to changing clay content. Even if the proper correction could be made, however, the effects of tool stand-off would remain. Until recently, the ODP neutron and density tools were eccentered with bow springs rather than with the usual hydraulic arms. Clearly, in a large diameter, rough borehole in soft sediments, the bow springs are unable to provide consistent eccentering.

\section{Site 718}

Compressional-wave velocities determined on cores are, except for some short intervals, generally lower than the downhole measurements from Hole $718 \mathrm{E}$ (Fig. 5, backpocket). This difference can be ascribed to drilling disturbance and rebound. However, the intervals that show similar compressional-wave velocities for laboratory and downhole measurements are lithologically different from other sections. The deposits there are evidently more indurated (they needed to be sawed when samples were prepared), and hence they were 


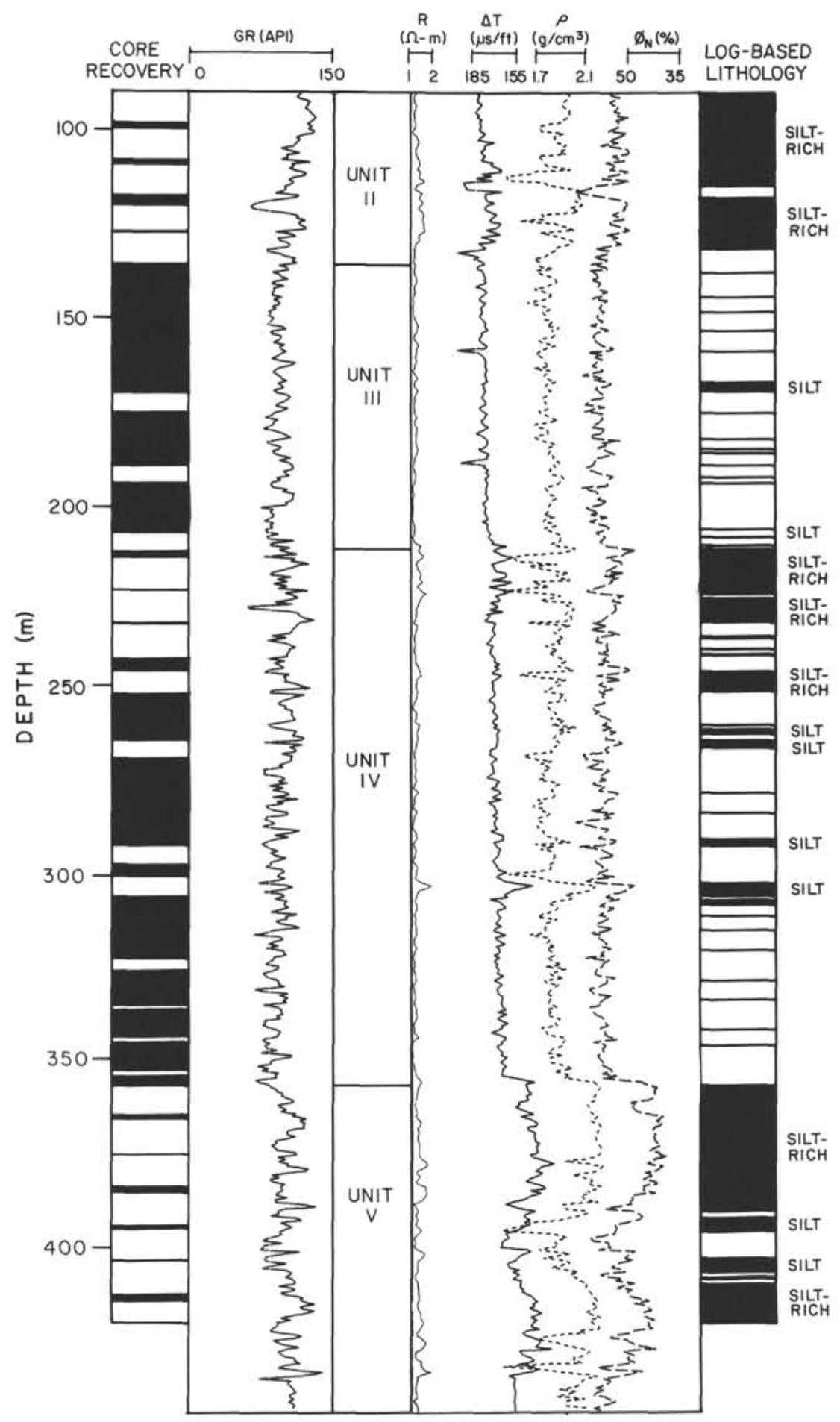

Figure 3. Compilation of wireline logging results (and derived lithology) and recovered intervals (black) and thereby defined lithologic units for Hole 719B. Abbreviations: GR, natural gamma ray; R, resistivity; T, compressional-wave velocity; $\rho$, density; and $\Phi$, porosity. The lithologic units are described in text. The derived lithology distinguishes between silt-dominated (black) and mud-dominated intervals. The former are characterized by lowered porosity, enlarged compressional-wave velocity, and density; for muddominated sections the relationships are inverse. 
probably less affected by drilling and porosity rebound (e.g., Marine Geotechnical Consortium, 1986).

Porosity was estimated from the sonic log data via the Raymer equations with an average matrix density of 2.75 $\mathrm{g} / \mathrm{cm}^{3}$ and a matrix velocity of $5.5 \mathrm{~km} / \mathrm{s}$. Values for $V_{1}$ and $V_{2}$ were determined from comparisons of rebound-corrected core porosities with the log velocities. The values determined on samples and by wireline logging are in good agreement except in intervals of low sonic velocity and large hole diameter. As with the data from Site 719 , the small-scale disagreement between the two techniques can be attributed to differences in the scales of measurement, uncertainties in the rebound correction, and limitations in the universal applicability of the Raymer equations.

An independent value of in-situ porosity was estimated by compression tests on core samples. The simulated in-situ value coincides within the range of error with the log porosity throughout the hole. The compression test porosities are consistent with the core-sample porosities.

\section{DISCUSSION AND CONCLUSIONS}

Mass physical property data determined on board and by downhole logging correlate to a varying degree with each other depending on lithology and the determined parameter.

Compressional-wave velocity values determined on board are of low reliability because they are heavily affected by drilling disturbance and rebound. The type of disturbance can be derived from comparisons with porosity; the case of opening of microcracks is very probable; porosity remains nearly unchanged whereas sonic velocity is drastically lowered. Only within more indurated intervals are downhole measurements and some on-board determinations of sonic velocity similar to each other.

Porosity and wet-bulk density are inversely related to each other. Here only porosity is discussed. At both sites the pattern of divergence between laboratory and downhole measurements seems to be controlled by lithology, although the accuracy of the downhole measurements varies among the logging tools. Major differences between on-board and in-situ determinations occur in lithologic units that contain an increased proportion of mud, mainly (1) mud turbidites with low silt, (2) pelagic mud turbidites, and (3) pelagic clays. However, it is not clear to what extent this correlation of error in the logging measurements with lithology reflects tool stand-off in the soft sediments rather than mineralogical effects. While some of the neutron-porosity overestimate (approximately $5 \%$ ) can be attributed to increased clay content, the most likely source of error is the improper eccentering of the tool. The density log, in particular, is not generally sensitive to clay content, so the difference between it and the core measurements clearly reflects adverse measurement conditions. The sonic log-derived porosities appear to be accurate independent of lithology, although this conclusion must remain tentative because of the poor core recovery within the silt-rich turbidite intervals.

An independent check of the accuracy of the various measurement techniques follows from the compression test results. They are in good agreement with all logging data in silt-dominated intervals and in good agreement with the sonic $\log$ data and laboratory data only in the mud-dominated sections. These results indicate that, until the techniques for eccentering the neutron and density tools are improved, only the sonic and resistivity logs should be used for porosity determinations in these high-porosity sediments. The core measurements are necessary for calibrations because the applicability of the resistivity and sonic-velocity transforms remains uncertain. In these terrigenous sediments from the Indian Ocean, the Raymer transform for sonic data proved most reliable while Archie's Law for resistivity failed completely. Jarrard et al. (1989), however, found the reverse to be true in high-porosity terrigenous sediment from the Labrador Sea. The reasons for these contradictory results are unknown.

\section{ACKNOWLEDGMENTS}

Financial support to A. Wetzel by the Deutsche Forschungsgemeinschaft is gratefully acknowledged.

\section{REFERENCES}

Archie, G. E., 1942. The electrical resistivity $\log$ as an aid in determining some reservoir characteristics. Trans. Am. Inst. Min. Metall. Pet. Eng., 146:54-67.

Borehole Research Group, 1987. Wireline Logging Manual (2nd ed.): New York (Lamont-Doherty Geological Observatory, Columbia Univ.).

Boyce, R. E., 1976. Definitions and laboratory techniques of compressional sound velocity parameters and wet-water content, wet-bulk density, and porosity parameters by gravimetric and gamma ray attenuation techniques. In Schlanger, S. O., Jackson, E. D., et al., Init. Repts. DSDP, 33: Washington (U.S. Govt. Printing Office), 931-958.

Bryant, W. R., Wetzel, A., Taylor, E., and Sweet, W. E., 1986. Consolidation characteristics and permeability of Mississippi Fan sediments. In Bouma, A. H., Coleman, J. M., Meyer, A. W., et al., Init. Repts. DSDP, 96: Washington (U.S. Govt. Printing Office), 797-809.

Cochran, J. R., Stow, D.A.V., et al., 1989. Proc. ODP, Init. Repts., 116: College Station, TX (Ocean Drilling Program).

Demars, K. R., and Nacci, V. A., 1978. Significance of Deep Sea Drilling Project sediment physical property data. Mar. Geotechnol., 3:151-170.

Ellis, D. V., 1987. Well Logging for Earth Scientists: New York (Elsevier).

Hamilton, E. L., 1976. Variations of density and porosity with depth in deep-sea sediments. J. Sediment. Petrol., 46:280-300.

Jarrard, R. D., Dadey, K. A., and Busch, W. H., 1989. Velocity and density of sediments of Eirik Ridge, Labrador Sea: control by porosity and mineralogy. In Srivastava, S. P., Arthur, M. A., Clement, B., et al., Proc. ODP, Sci. Results, 105: College Station, TX (Ocean Drilling Program), 811-835.

Karig, D. E., and Salisbury, M. H. (Convenors), 1986. Measurements of physical property and mechanical state in the Ocean Drilling Project. Report of a workshop held at Cornell University 26-28 June 1986: Washington, D.C. (Joint Oceanogr. Inst.).

Marine Geotechnical Consortium, 1986. Geotechnical property of northwest Pacific pelagic clays: Deep Sea Drilling Project Leg 86, Site 576A. In Heath, R. C., Burckle, L. H., et al., Init. Repts. DSDP, 86: Washington (U.S. Govt. Printing Office), 723-758.

Nichols, T. C., Jr., 1980. Rebound, its nature and effect on engineering works. Q.J. Eng. Geol., 13:133-152.

Raymer, L. L., Hunt, E. R., and Gardner, J. S., 1980. An improved sonic transit time-to-porosity transform. Trans. SPWLA 21st Annu. Log. Symp., Paper P.

Schmertmann, J. H., 1955. The undisturbed consolidation behavior of clay. Trans. Am. Soc. Civ. Eng., 120:1201-1227.

Serra, O., 1984. Fundamentals of Well-Log Interpretation: New York (Elsevier).

Terzaghi, K., and Peck, R. B., 1967. Soil Mechanics in Engineering Practice (2nd ed.): New York (Wiley).

Wyllie, M.R.J., Gregory, A. R., and Gardner, L. W., 1956. Elastic wave velocities in heterogeneous and porous media. Geophysics, 21:41-70.

Date of initial receipt: 26 April 1989

Date of acceptance: 6 February 1990

Ms 116B-146 